\title{
Is the South so different? \\ Italian and Spanish Families in a Comparative Perspective
}

Teresa Jurado Guerrero and Manuela Naldini

Article published in South European Society and Politics, 1996, 1:3, pages 42 - 66.

Summary:

This article analyses family changes in Italy and Spain from 1960 to 1990 and contrasts them with four Central/Northern European countries. Italy and Spain show extremely rapid family changes, which nevertheless do not lead to a convergence between southern and central/northern families. The particularities of the southern family model are a high degree of cross-generational cohabitation, a high frequency of social contacts and help within kinship, a strong institutionalization of marriage, a low female employment rate in the formal labour market, a low fertility rate, and widespread family and child-oriented attitudes. In addition, relations between generations are seen more in terms of obligations than in terms of individ- 
ual choice. We conclude that the specific economic situation, the particularities of social policies and the family culture in Italy and Spain are important barriers for a further individualization of family relations in these societies.

The aim of this paper is to analyse Italy and Spain as representatives of a Mediterranean type of society. ${ }^{1}$ The question whether such a type exists with respect to family changes will be explored here. For this purpose we use a comparative perspective. Our assumption is that the division of labour between state, family, labour market and church in Mediterranean countries is a specific one. The societal configuration in the South will be analysed from the perspective of the family. First, we will describe differences in demography and family among countries as well as cultural differences observed by opinion surveys. Second, we will develop some hypotheses in order to explain the southern family characteristics, their interrelations and their relation to other institutions. To this end, we will concentrate on the possible effects that southern modernization processes, employment and unemployment trends, family laws, social policies and some historical and cultural peculiarities in Italy and Spain have on family patterns. In this paper the hypotheses will be put forward only in a preliminary way, without testing them.

The socio-economic crisis that has affected all European countries since the mid-seventies has gradually produced a collective loss of faith in the possibility of uninterrupted economic growth and disillusion concerning the programmes and promises of the welfare society. As a result of the crisis, the institutional framework began to change and the social division of responsibilities among the various institutional spheres, state, market and family, had to (and still has to) be re-negotiated (Flora 1985). In the new social and economic context, the interest in the family in the analysis of western-welfare society has become wider.

From a cross-national perspective it is often assumed that southern welfare states have a different division of labour between state, market and family than other Northern/Central European societies (Ferrera 1994). Studies on this field show that, despite the development of the welfare state, the family and the 'serving work' (Balbo 1983) carried out by women in southern welfare societies have continued to constitute an indispensable resource for the satisfaction of many basic needs.

The changing age structure of the population, the decreasing fertility rate and the emerging female employment patterns in Italy and Spain may affect the southern division of labour in 
an important way. While analysts are emphasizing the importance of the family for the satisfaction of many basic needs in this welfare state crisis period, the most "family-oriented" ${ }^{2}$ countries are moving towards a more individualistic society? Is this a contradiction? First of all, it needs to be determined to what extent the family is changing in the South and therefore we will give a general overview on these changes in the European context.

Since 1965, in most European countries - with varying intensity and timing - a reduction in the fertility rate and an increase in the divorce rate has taken place. These new family behaviours have been related to the gradual diffusion of cohabitation and to the increase in births out of wedlock. During the 1970s these family changes became more radical in Scandinavia and more widespread in Central Europe, but they remained weak in Southern Europe. What was really new were the relations between sexes and generations. Equal opportunities became an important issue in public life (Roussel 1992), and changes in family roles also occurred. More women have entered the labour market, in a wider range of occupations and for a longer period than at any other time since the Industrial Revolution (Rapoport 1989). 


\section{A SOUTHERN EUROPEAN FAMILY MODEL?}

In the field of family structures, Roussel $(1992,1994)$ has classified European countries, on the basis of demographic indicators, into three homogeneous geographical groups: the Scandinavian countries (Sweden, Norway, Finland, Denmark and Iceland), which were at the forefront of family changes given the increasingly numbers of cohabitation and births out of wedlock; Central Europe (Germany, France, Belgium, Luxembourg, Switzerland) which soon followed the family model of Scandinavian countries; and finally, the Mediterranean countries (Spain, Italy, Greece and Portugal [and Ireland]) which have only recently adopted the 'new' family pattern and this in a contradictory way. So far, the main question is: how can we explain the persistence of differences in family structures and behaviours across countries? Are they due to timing differences or pattern differences?

An overview of Italian and Spanish families shows that several similar demographic phenomena changes have occurred, especially in the last decades. First of all, it is well known that since the 1980s the dominant phenomenon in Italy and Spain has been the rapid decrease in the fertility rate to unprecedented low levels in comparison to other countries. Secondly, in these countries unmarried youth remain longer in their parents' households and kin and solidarity networks are more intense than in other European countries, with single-person households remaining the exception rather than the norm. Thirdly, in Italy and Spain the numbers of divorces, cohabiting couples and births out of wedlock are still low (Flaquer 1994). In other words, the degree of institutionalization of marriage as a central family institution seems to be higher and family solidarity more important in Italy and Spain than in Central/Nothern European countries. ${ }^{3}$

At a first glance, these changes and the present family patterns in these two southern countries could be interpreted as the result of late modernization processes. To be sure, this interpretation is partly correct, but some aspects of it cannot be understood from this perspective. First, Italy and Spain both show indicators of modernity in the family (e.g. rapid decline in fertility) and indicators of traditionality (e.g. marriage as an institution is still very important). Second, the modernization process has not led to the same results in each country, because traditions and cultural contexts have been incorporated differently during industrialization. For example, the economic importance of small enterprises in some areas of Italy shows how a specific family tradition (the spread of the extended family) can produce a special kind of modernization. Modernization does not, therefore, affect all areas of society in the same de- 
gree.

\section{ITALY AND SPAIN: AN OVERVIEW OF SOCIO-POLITICAL CHANGES}

First, we will briefly describe the socio-political context of the two countries. In Italy and Spain, modernization has been very rapid. In Italy, it took place later than in other European countries, between the end of the 1950s and the beginning of the 1960s. In Spain, it started later and was even more rapid than in Italy, as Figure 1 shows. This period of modernization was also characterised in these countries by a structural employment shortage and by profound geographical differentiations within the two countries, which prompted great internal and external migrations from the 1960s until the mid-1970s.

The process of family change in Italian and Spanish societies was related to changes both in the social stratification and in the economic development of the countries and were accelerated by an intensive and rapid development of the welfare state (cf. Figure 1). Indicators of discontinuity in family values and attitudes - first in behaviours and then in legislation started to appear in Italy in the mid-1950s and accelerated in the second half of the 1960s. In Spain, families began to transform at the end of the 1960s, but because of the comparatively high number of members in Spanish families, the low number of publicly financed places for child care, and the low level of consumer goods to facilitate housework in Spanish households, the traditional ideas about the division of labour within the family and the authoritarian political system made further changes difficult before democratization was instituted. In Spain an important factor for changes in the family was the imitation of West European behaviour. As result of tourism, emigration and the mass media, new ideas penetrated Spain (Conde 1982). 
Figure 1: Indicators of Modernisation and Wealth, Spain and Italy 1961-1993
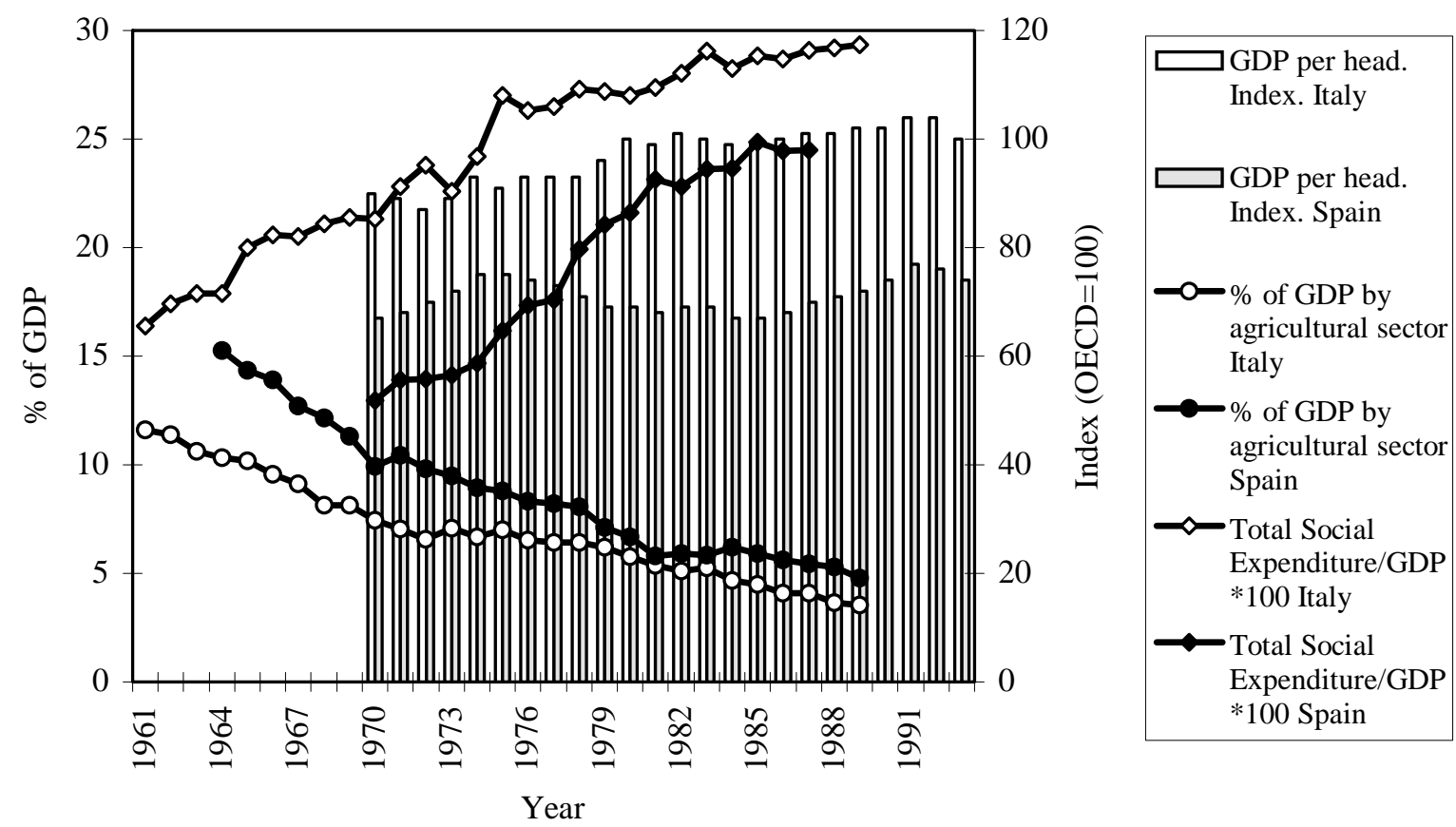

Sources: For \% of GDP per sector: OECD, 1980, 1989 and 1991. MZES, 1994. IC 1. For total social expenditure: Alcaide Inchausti, 1988. Tab. 24, 25 and Ferrera, Tab. 4, 1984. For GDP per head: OECD, 1995, p. 148.

The Italian welfare state mostly developed during the 1970s and early 1980s, and soon reached average European levels, despite the fact that during the 1950s it had been one of the least developed of Western European countries (Ascoli 1984). During the 1970s there was also the maximum expansion of social and caring services (kindergartens, day care for children under three, home help for elderly, and so on). In Spain, the welfare state expanded especially during the 1980s, about ten years after Italy. The different social security systems were enlarged in general, health and old-age pension benefits were universalised and new assistance schemes were introduced (Guillén 1992).

As a result of the specific political-ideological configurations of the two countries, the process of legal change began only in the 1970s in Italy, and in the 1980s in Spain. Italy changed its institutional-political framework after Fascism and World War II, but despite this, family relations were strongly influenced by the traditional values and norms defined by the Catholic church and codified during fascism (i.e. codice Rocco in 1942). For more than forty years, the Christian Democratic Party was the main governmental force. This configuration of a strong Christian Democratic Party and a strong Catholic Church favoured the permanence of traditional family patterns and the delay of family law reform. The case of Spain was similar: there 
a Fascist dictatorship, together with the support of the Catholic church, prevented a change in family-related legislation until the end of the 1970s.

In Italy, the 1970s saw a real process of modernization and secularization: important legislation concerning gender roles and the family was approved; divorce was introduced in 1970; family law was reformed and modernised in 1975, the same year in which the age of majority was lowered to 18. Equal treatment between men and women with respect to work was introduced in 1977, and abortion was legally authorised in 1978 (Vincenzi Amato 1988). In Spain, after the end of dictatorship, from 1975 to 1981, the society experienced a singular process of peaceful and gradual transition to a pluralistic, democratic political system. With the reform of the 'Código Civil' in 1981, civil marriage became an option for citizens. Questions regarding marital breakup passed from the responsibility of the church to that of the state. These reforms also led to equality between spouses: wives were no longer legally bound to obey their husbands. Financial questions in marriage, questions of infidelity, paternity, children born out of wedlock and other family matters were also changed (Alberdi/Alberdi 1982). Since the mid-1980s abortion has been legal in some cases, and cohabiting and homosexual couples can register their unions in municipalities.

In countries like Italy and Spain, where rapid modernization has taken place, incongruencies can be noted in the process of social change: between the economic, demographic and family changes, on the one hand, and the legislative and welfare-state transformations, on the other, as well as between geographical areas, which have developed very differently in economic terms. The rapidity of the changes, has made adaptation very difficult. In Spain and in Italy, great regional cleavages in economic development have influenced family changes and the development of the welfare state, delaying or even preventing them in the more backward regions (Conde 1982, Paci 1982).

\section{FAMILY CHANGES IN ITALY AND SPAIN IN THE EUROPEAN CONTEXT}

We will describe the changes which have occurred in the family mainly on the national level ${ }^{4}$ and by looking at the different phases of the family cycle. The concept of family cycle is useful, because family patterns vary not only geographically, but in the same family unit over time. However, we have decided to analyse employment and work behaviour in a separate section, because of difficulties in relating existing data to the different phases of the family cycle. Spain and Italy will be compared to four Central/Northern European countries, which 
differ along the dimension of the prevalent religious denominations and in the type of welfare states they have: they are Denmark, France, the United Kingdom, and the former German Federal Republic.

The analysis of family changes can be made at two different theoretical levels. First, the relationships between different societal institutions can be studied, i.e. the relations of the family with the state, the church and the labour market. Second, the 'black box' of what is meant by family can be opened. At this second level of analysis the family can be seen as a unit structured by the dimensions of gender and generations or as a unit related to other family units in social networks. In order to discuss the specific societal division of labour in the South we will first focus on the second level of analysis: the functioning of the family and, in a second step, we will try to relate this to other societal institutions.

\section{Changes in the Family Formation Phase : Marriage Patterns and Values}

According to Golini, 'one of the most important characteristics of the recent Italian demographic developments is the reduction of the number of marriages' (Golini 1988). This change started in the 1970s, later than in other European countries, and it is common to all regions but is more substantial in those of the Centre and of the North (Golini 1988). In Spain, the gross marriage rate has decreased in general since 1981 with a certain regularity of stability from 1986 to 1990. For 1982 one can also detect regional differences in Spain, but they do not seem to be very important, nor are they clearly structured (Delgado 1993, Eurostat 1992b).

So far, the data seem to support the hypothesis of delayed marriages. In fact, in Italy the total number of marriages has decreased, but above all among young women. At the same time the marriage rate of women over 25 has increased (Golini/Menniti 1994). The share of the population that has changed most rapidly its behaviour is that of the women living in large towns of the Centre and the North (Golini 1988). In Spain, too, the data show that since 1980 the percentage of people marrying before the age of 25 is decreasing. The average age of women who have married for the first time rose in 1990, and remains lower than in Denmark, France and Germany although it is higher than in the United Kingdom (Delgado 1993). In Spain and Italy, a number of circumstances favour the delay of marriage: high unemployment rates and increasingly precarious employment for young people, expensive housing, the re- 
cent extension of high education, and cultural shifts after 1968 concerning sexual relations before marriage. Another indicator of changing marriage patterns in Italy and Spain is the increase in civil marriages in the last decade.

Can the delay of marriages and the increasing civil marriage rates be viewed as indicators for negative attitudes toward the institution of marriage? To understand this, we will examine attitude surveys in a comparative perspective. ${ }^{5}$ In the World Values Survey 1990-1993, people were asked to give their opinion concerning the statement 'Marriage is an out-dated institution'. Their responses are shown in the table below.

Table 1: Opinions about 'Marriage is an Out-dated Institution', 1990-1993

\begin{tabular}{|r|r|r|r|r|r|r|r|}
\hline $\begin{array}{r}\text { Column } \\
\text { \% }\end{array}$ & Italy & Spain & DK & F & UK & ex-FRG & $\begin{array}{r}\text { Groupe- } \\
\text { average }\end{array}$ \\
\hline Yes & 14.1 & 16 & 18 & 29.1 & 18.4 & 15 & 18.4 \\
\hline No & 85.9 & 84 & 82 & 70.9 & 81.6 & 85 & 81.6 \\
\hline
\end{tabular}

Source: World Values Survey, 1990-1993, var. 216.

As the table shows in the majority of countries few respondents said that marriage is outdated, and the differences between countries are not very relevant. These figures support the idea that marriage as an institution is highly valued in most of the countries analysed, with the exception of France.

Another indicator for measuring the degree of institutionalization of marriage is the diffusion of alternative living arrangements. In Italy and Spain, existing data point to the low presence of the phenomenon of cohabitation (Eurobarometer 1991a). Among couple-based families, the percentage of unmarried couples in Italy is very low in comparison with other countries, although, as some analysts suggest, this number may be largely underestimated in regard to Italy (Sabbatini 1991). In any case, in Italy this phenomenon is more common in the northwest, in urban areas and among higher-educated people and employed women. Moreover, peculiar to Italy, most unmarried couples are separated or divorced, and are not formed mainly by young people as is the case in other countries. In Spain, most cohabitants are young people (18-34), and in contrast to Italy, they are not practising Catholics and they live predominantly in urban areas, more frequently in the regions of Cataluña, Madrid and País Vasco (Valero 1992).

So far we have shown that Spaniards and Italians marry later and more often by civil ceremony following the Central/Northern European pattern. However, the range of individual choices in family formation is narrower in the South; Italians and Spaniards normally neither 
cohabit nor live on their own when they are young but instead stay longer in their parents' household. Despite the number of single-person households is increasing, very few young people live alone in the South, thus the elderly dominate nearly completely this type of household differently from other European countries (Eurobarometer 1991a, Istat 1993, INE 1991). An international comparison of young people shows that in Italy and Spain youths stay longer with their parents than in the other countries. Can this southern phenomenon be explained by the employment/unemployment condition of young people? To understand this, we have correlated the national unemployment rate of young people with the rates indicating their living arrangements. As illustrated in Figure 2 there is a relation between both rates in the case of the youngest age group, especially for Italy, Spain and the United Kingdom. 
Figure 2: Unemployment and Living in the Parental Home, 1990-91
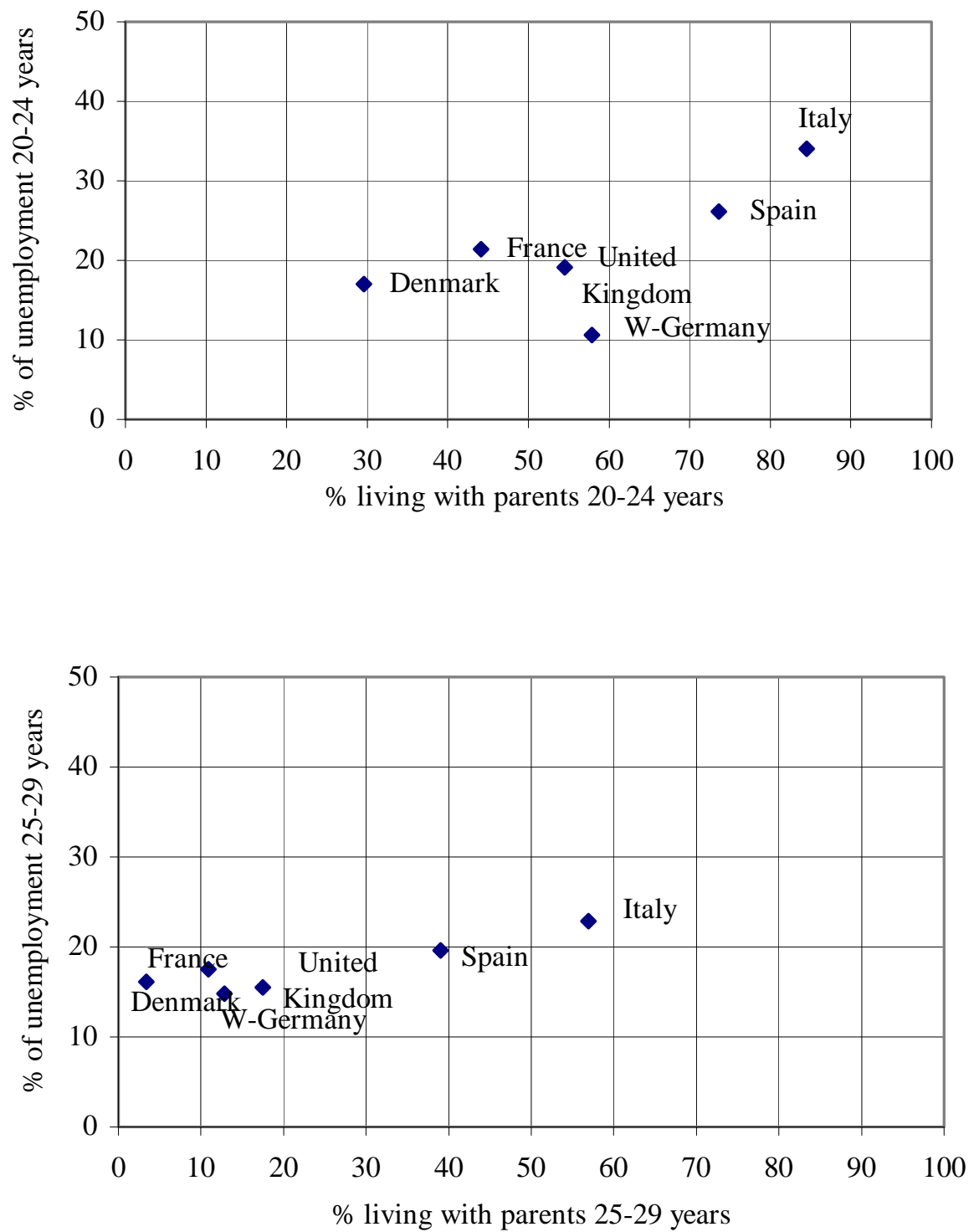

Source: For living with parents: World Values Survey, 1990-93, var. 357, 355. For unemployment: Eurostat, 1993.

For France and West Germany this correlation does not appear to be particularly strong, because despite relatively high unemployment in France, young people seldom live with their parents and because West Germans live relatively often with their parents despite low unemployment. In addition, it is also evident that the great differences in living arrangements between countries cannot be explained by variations in unemployment rates, because the latter are much smaller than the former. In the case of young people from 25 to 29, variations in unemployment rates between countries are not so large, but variations in their living arrangements are. This means that unemployment does not explain everything. Recent Italian re- 
search shows that a substantial percentage of young women live in their parents' home even when they have a job (Menniti et al. 1992). Is it a cultural peculiarity of Italy and Spain which makes it acceptable and even desirable for young people to stay with their parents for a long time? Cavalli's surveys on this issue argue that young people prefer to remain in their parents' home, with economic support and social security being supplied, together with personal freedom (Cavalli et al. 1993). In addition, being in school can be a barrier to leaving the parental home, but perhaps to a higher extent in some countries than in others. In Italy and Spain, most students stay at home until they finish their education, whereas in other countries the tradition seems different. To conclude, it can be said that marriage is more highly institutionalised in Italy and Spain because alternative living arrangements such as cohabitation and single-person living arrangements are not yet institutions, and are still viewed as acts of individual will which break with routine, and which may well not be positively sanctioned. As a result this implies a high institutionalization of parents and adult children cohabiting before marriage.

\section{Changes in the Family Expansion Phase}

The family expansion phase analysed with national data shows similar changes and features in Spain and Italy. These changes are similar to these to Central/Northern Europe, although delayed by a few years. In Italy, the decline of fertility began rapidly, in the middle of the 1960s, and before that in Spain. Spain rapidly caught up and reached similar levels in the fertility rate (cf. Figure 3). Similarities with other European countries can be found in the increase of the mean age at first birth, in the reduction of childbearing among very young women, and in the stabilization of fertility rates after age 30. 
Figure 3: Total Fertility Rates at European, National and Regional level 1960-1990

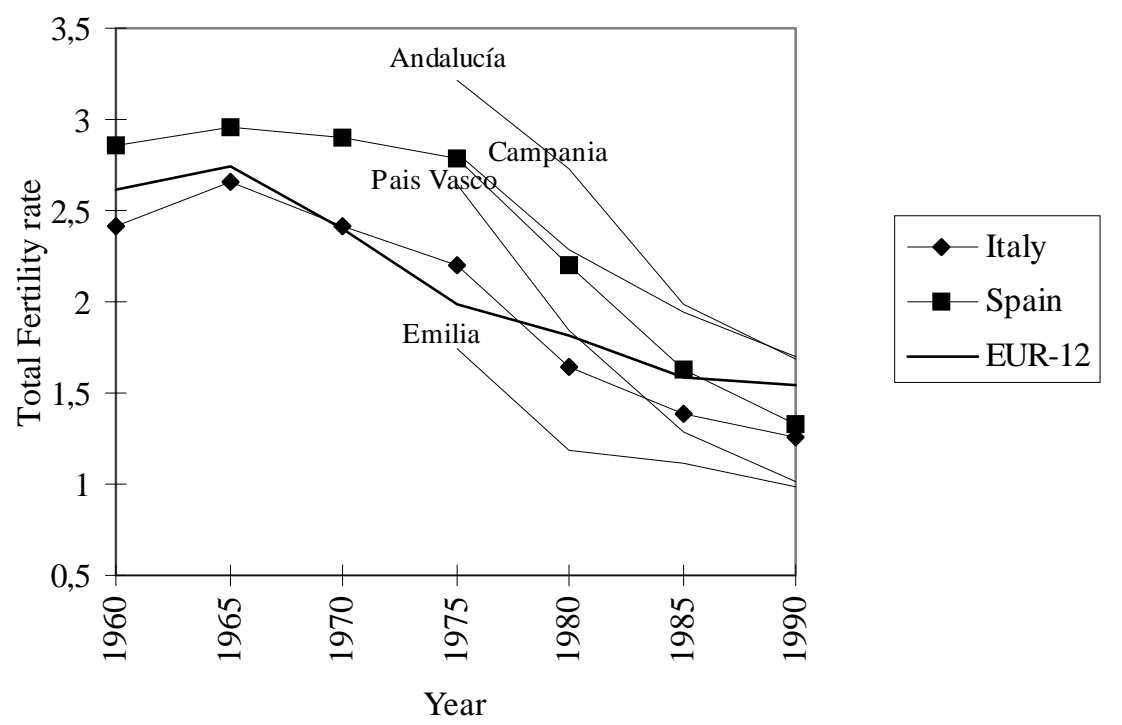

Source: Eurostat, 1992b, E-9. Delgado Pérez/Livi-Bacci 1992.

What makes Italy and Spain similar to and different from Central/Nothern European countries? First, Spain and Italy have a very heterogeneous fertility patterns between regions, while other European countries are more homogenous (Delgado Pérez/Livi-Bacci 1992). In Figure 3, the fertility rates of the two most disparate regions in Italy and Spain are illustrated. It is curious to see how in both countries the two regions with the highest fertility rates in 1975 have over time converged to the same fertility level in the same way as have the regions with the lowest fertility rates. Differences at the territorial level should not be underestimed because they are indicators of different family cultures within a country (Saraceno 1994b).

The second way in which Italy and Spain differ from their European environment is that the decline in fertility correspond to a shrinking marital fertility, because birth outside marriage in both countries is a minority phenomenon (Eurostat 1992b). In other words, the birth of children is in these countries more strongly related to marriage than in Central/Nothern European countries, and has to be seen in relation to the delay of marriages as described earlier.

How can the low fertility rates in Spain and Italy be explained? It is difficult to view them as the result of modernization or by using the explanations given for other West European countries (higher rates of female employment, higher rates of female participation in education, the sexual revolution, and secularization). The reduction of fertility rates in the South occurred and accelerated in the presence of the following factors: 1) a lower rate of women in 
the labour market in comparison with other European countries; 2) a gender divergence in education that remained stable until the 1970s (later than in other countries); 3) legislation that up to 1975 in Italy and 1978 in Spain prohibited abortion as well as the dissemination of both knowledge and use of contraception; even after abortion and contraception were legalised, only an incomplete contraceptive revolution took place, as Delgado and Livi-Bacci have pointed out; 4) the strong influence of the Catholic church on political, cultural and daily life, although to a different degree in Italy and Spain (Saraceno 1994a). Indeed, in Spain the power of the Church was actually restricted during the democratization process.

Thus, do Italians and Spaniards not like children? Europeans were asked how important it was for them to have a child. The findings confirm the central and fundamental role of children in all countries but with important differences. The percentage of people who consider having a child as essential and very important number 72.9\% in Spain, 71\% in Italy, 67.3\% in France, 63.3\% in Denmark, 57\% in the United Kingdom and 56.2\% in West-Germany (Eurobarometer 1993). In addition, in Spain, Italy and France people answered to be important to have children for their marriage to be successful (World Values Survey 1990-1993). One possible conclusion is that the Italians, Spaniards and French are more child-oriented than the Germans, English and Danes. One could also say that Italian and Spanish people attribute to children an important role in increasing solidarity within the couple, as shown by the higher percentage of Italians and Spaniards who consider having a young child as a good reason for not getting divorced.

If people in Spain and Italy are comparatively highly child-oriented, then why has the fertility rate decreased? Some Spanish and Italian analysts suggest that the major explanatory factor for the drop in fertility is the late and massive entry of Italian and Spanish women into the labour force since the 1970s. These changes have occurred so fast that the two societies may not have adapted to them rapidly enough, it means that social services, the level of family allowances, labour legislation, housing, etc. and social norms inside the family have not changed at the same rate as female employment has. It also seems significant that Italy and Spain are among the countries with the least generous child benefit packages of all European countries (Bradshaw/Ditch 1993). If this analysis is correct, the conclusion can be drawn that childbearing presents greater opportunity costs to Italian and Spanish women than to women in other Central/Nothern European countries, where women's participation in the nonagricultural sector of the labour force has a longer tradition, as well as public measures to combine employment and family (Delgado Pérez/Livi-Bacci 1992). The delay of marriage 
surely also has consequences for fertility rates delaying and reducing the number of births. As a consequence, the causes for the delay of marriage (high unemployment rates among the youth, long education phase, housing shortage, etc.) may well influence the fertility level in an indirect way. We should also note as well that Catholicism has not been able to halt this decline in fertility in the Southern European countries, unlike the case of Ireland.

\section{Changes in the Family Shrinking Phase}

The South also displays specific characteristics in the shrinking phase of the family. In Italy and Spain, as in other Catholic countries of Western Europe, divorce laws were introduced later than in other European countries, in only 1970 in Italy and in 1981 in Spain. When such laws are introduced so late in the socio-economic development of a country, the demography of the people who obtain divorces shows very different patterns to that of other countries which have implemented this earlier. Couples who were married and perhaps de facto separated for a long time can thus divorce and, as a result divorcing partners and the children affected by the divorce are older (Goode 1993). In Barbagli's analysis Italy is distinct from the other industrialised Western countries in a number of ways, even though the same general tendencies are observable (Barbagli 1990). The most distinctive feature of divorce in Italy (and Spain) is that it is still not a substitute for a separation but is simply added to a separation as a legal step. This also makes divorce in these countries more costly than in other European countries (Alberdi/Alberdi 1982).

The analysis of data reveals that in both countries more people sought legal separation than divorce, at least until 1991. Nevertheless, the divorce rates in the South are still very much lower than those in Central/Nothern countries. In 1989, the number of divorces per 1,000 population was 0.6 for Spain, 0.5 for Italy and 1.6 in Europe of the Twelve (Eurostat 1992b). A correct comparison between Italy, Spain and other countries in conjugal instability has to be made taking in account not only the number of divorces but also the number of legal separations, because many couples go no further than the separation stage (Alberdi/Flaquer/Iglesias de Ussel 1994, Golini/Menniti 1994). The evolution of the phenomenon has, and always had, differential values between North and South, but in both areas there is a tendency to increase. As Barbagli notes, in many northern Italian towns the legal separation rate is not so very different to that of the Swedish divorce rate. 
Another difference Barbagli reports for Italy is a definite correlation between the number of children and a reluctance to divorce: fewer couples with many children get divorced than do couples with few children, as opposed to other western countries (Barbagli 1990). A Eurobarometer survey supports this (1993); it shows that among all Europeans the presence of children is for every country felt to be the first good reason for not getting divorced, but that the percentage of Italians and Spaniards supporting such an idea is higher than that of other Europeans. For Spain, in a national analysis of divorces from 1981 to 1986, Borrajo found that controlling for the length of marriage, legally separated or divorced couples did not generally have fewer children than married couples, i.e. having children did not prevent the marital breakup. An exception were the couples married for between two and eight years, of which the separated or divorced had fewer children than the sill married (Borrajo 1990).

One explanation for the low divorce rate in the South may be the higher institutionalization of life-long marriage in contrast with a vision of a more contractual marriage. However, in order to prove such a hypothesis the future development of divorce in Italy and Spain will have to be observed, because its legal introduction is still too recent to show anything definitive as yet.

\section{Changes in the Gender Division of Work in the Labour Market}

In this section we will try to offer hypotheses on the low female employment rate and the peculiar career patterns of employed women in Italy and Spain. These countries had a very low rate of female labour participation after the Second World War, with Spanish women, over time, less likely to be employed than Italian. During the 1950s and until the mid-1960s, the female activity rate increased in Spain, while in Italy, as a consequence of the first phase of industrialization, it decreased. Since the beginning of the 1970s, female labour force participation has increased in both countries, with a greater speed in Italy than in Spain. What has been really new for both countries, however, is that the female labour supply is no longer strictly dependent on the market demand but is more and more influenced by women's willingness to go into the labour market. An important historical feature of both countries is the structural shortage of employment, which has affected women's labour force participation in the South in contrast to Central/Northern Europe. In addition, regional differences in the employment structure were and still are important. Despite the rapid increase in southern female 
activity rates from around $20 \%$ in the 1970 s to around 35\% in the 1990 s they are still the lowest among the European countries analysed, reaching only 2/3 of the Central/Northern European activity rates. As well as this difference, women in the Spanish and Italian labour markets are also integrated in different ways than Central/North Europeans.

Analysing comparative data on employment in Italy and Spain and especially data on female employment it should be made clear that the labour markets in these two countries are characterised by the high number of 'black' or 'grey’ jobs. These jobs, mainly held by women, are distinguished by precarious social security, specific time patterns (seasonal jobs, definite time-period contract, and part-time work), and low pay (Muro et al. 1988, Solsona 1991, Paci 1980). From our point of view there are three main peculiarities of the recent entrance of women into the labour market in Italy and Spain: 1) the growth of female activity rates meant and still means an increase in women's unemployment rates. The gender division of unemployment is much more clear-cut in Italy and Spain than in other countries (cf. Figure 4); 2) women's part-time employment is very low. In 1989 10.9\% of the Italian women in the formal labour market were employed part-time vs. $11.9 \%$ in Spain. In France the part-time rate was 23.8\%; in West Germany, 30.7\%, in Denmark, 40.1\%, and in the United Kingdom 43.6\% (Eurostat 1991, Eurobarometer 1991b); 3) In Italy and Spain, as shown in Figure 4, there is a generally lower development of the service sector, traditionally occupied by women in Central/Nothern countries, and a higher proportion of employed people in the agricultural sector. 
Figure 4: Activity, Employment and Unemployment

- Agriculture $\square$ Industry $\square$ Services $\square$ female activity rate

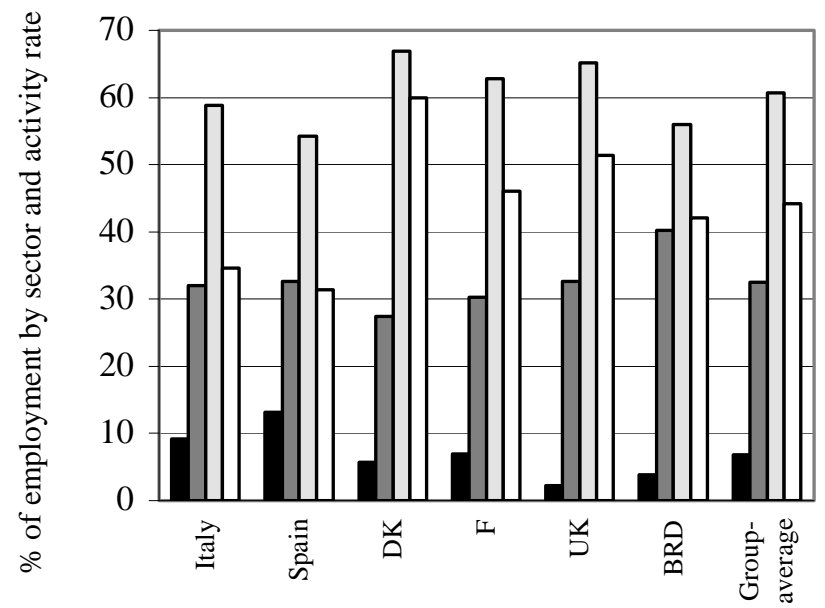

all $\quad$ awomen

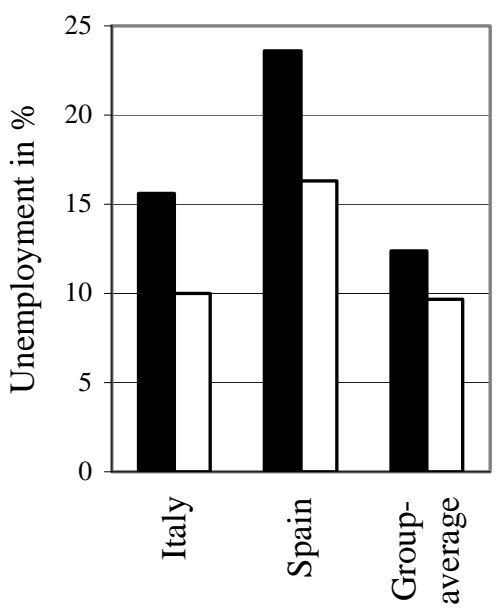

Source: Eurostat, 1992a, p.41; 1991, p. 96.

To sum up: the above-mentioned structural employment shortage, the low part-time employment and the lower development of the service sector can partly explain the low female employment rate in these two countries.

As far as the specific career pattern of employed women is concerned, a longitudinal study on employment and family in the EU carried out for Eurobarometer in 1991 shows clear differences in employment patterns of women across countries. Six differences can be identified, producing the following groupings of countries: 1) France and Belgium, 2) Denmark, 3) East Germany, 4) Greece, Portugal, Spain and Italy, 5) West Germany and Great Britain, and 6) The Netherlands, Luxembourg and Ireland. Women in Spain and Italy go late into the labour market, have a low entry rate, a very high continuity rate, and seldom work part-time. After the birth of their first child the majority of married women continue to work full time in Italy, whereas in Spain they either stop employment completely or continue with a full-time job. By contrast, in West Germany and Great Britain, women have a high initial entry rate, but low continuity, punctuated by long interruptions and high reliance on part-time work. A very high number of women leave the labour force after the birth of their first child (Eurobarometer 1991b).

As has been shown before, the situation of the labour market in these two countries is crucial for understanding the family changes. For Italy, a relationship between the level of female employment and the level of fertility, as well as of divorce, can be found by carrying out 
a regional variance analysis (Barbagli 1990). The low rate of female employment and the high presence of women in the informal sector and among precarious jobs favour an asymmetric relation between genders in the family.

\section{Solidarity Relationships and Family Values}

The demographic behaviour and the opinion survey data analysed above seem to support the idea that in Italy and Spain familial relations are seen more in terms of obligations than in terms of individual choice. In the following pages we want to illustrate how important the family in the South is in performing welfare tasks. To this end a brief analysis of family networks, attitudes toward religion, and family duties will be presented.

The analysis of family networks will be made at two different levels. First, intergenerational family relationships will be analysed by investigating the length of time different generations live together in one household. Second, the family and kinship networks will be described by the extension and intensity of contacts between different households.

In regard to the first dimension, the specificity of Spain and Italy lies in the lengthier periods of cohabitation which occur between the different generations. In Italy and Spain - much more than in other Central/Nothern European countries - old people and young people live with their families. In 1993, when asked if old people of 65 years or more lived permanently in their household, 13\% of Europeans answered positively. Within Europe great variations were however found. In France only 8\% said old people lived with them, 9\% in Denmark, 11\% in West-Germany, and 13\% in Great Britain. However, in Italy 19\% and in Spain 21\% had older people living with them. A similar picture emerges for young people, but with even greater international variations. As far as people living together is concerned, an important consequence of these living arrangements is that these people have necessarily a great deal of contact with each other - they can help each other and pool incomes more easily if they want.

The second level of analysis concerns the potential networks represented by the frequency of contacts and by the exchange of resources between households. The only comparative study on social networks available (ISSP 1986) does not include Spain. Thus, here we will analyse the Italian and the German cases as representative of two clusters of countries. Both the kin and friendship networks in Italy are wider than in Germany. Relatives in Italy live closer together than in Germany and visit each other more often, which means that individu- 
alization degree is in this sense lower in Italy than in Germany. Italian social networks, both kin and friendship networks, are characterised by a strong 'intensity' and 'localism'. What also seems different is that the intensity of relationships in Italy often extends beyond the relationships with mother and father (ISSP 1986, Bruckner/Knaup/Müller 1993). The more intense relations of Italians with their relatives is also related to a greater importance of these last for social and economic support. ${ }^{6}$ For help Italians mostly ask relatives (mother, father, but also sisters and brothers), and the help of the partner is relatively less important than for Germans (Bruckner/Knaup/Müller 1993). Germans have weaker kin networks than Italians, and they also have weaker friend networks in both extension and intensity. However, it should be taken into account that data is only a national average and that it does not provide information on geographical or social differences within the country (Sabbatini 1994).

Is Spain similar to Italy? A Eurobarometer survey of older people in 1992 gives some idea of this. People over 60 were asked 'how often do you see your family?' The results support our previous analysis on social networks in Italy and Germany (Figure 5).

Figure 5: Daily Visits of Elderly 1993

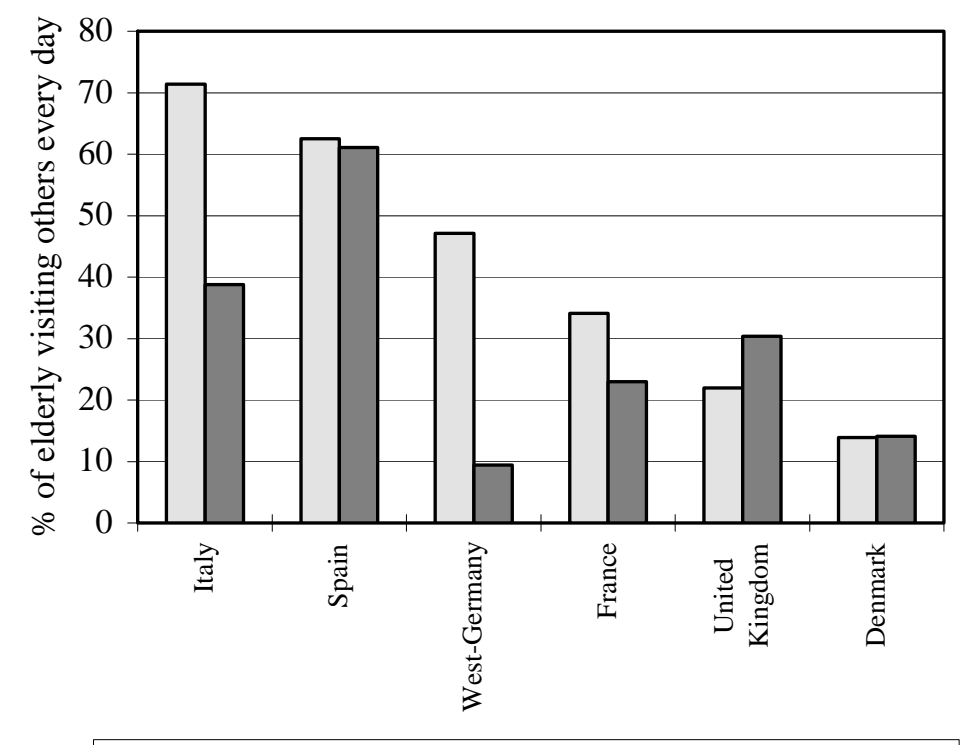

$\square$ Visit their family every day $\square$ Visit their friends every day

Source: Eurobarometer, 1992, 37.2.

The importance of helping networks within kinship is also reflected in how young people look for jobs. The results of the Eurobarometer study, 'Young Europeans' show considerable differences from country to country. 'Help from kinship and social networks (relatives and 
friends) is of primary importance throughout the Mediterranean (Spain, Greece, Portugal, Italy, and even France) [...].' By contrast, such help is less important throughout the countries of northern Europe (Commission of the European Community 1988).

Family members in the South interact more closely with each other, and kin networks are more important than in other countries. The fact that different generations live longer together, along with the high institutionalization of marriage, can help explain the higher density of contacts within and between families. But how can we explain the high level of support and solidarity within networks in these countries? Are they due to the high density of contacts or to other socio-economic characteristics? The level of economic development of a country (measured by the classic indicators of industrialization, urbanization and mobility) can only partly explain the lasting importance of family and kinship relationships in some countries. For example, Höllinger and Haller (1990) have proved that although Italy has a higher degree of urbanization than Austria, in Italy kin relationships are much more important. Other possible explaining factors to take in account can be historical differences in the frequency of extended families, religious denomination, the strength of the Church, differences in social policies, and in housing markets.

As far as attitudes towards religion are concerned we want now to present some southern particularities. The Catholic church in Spain and Italy has traditionally had a great influence on family matters. Despite an important secularization process in the last decades, religion is still very important in both countries from a comparative perspective. As Greeley has shown in a cross-national study, despite modernization, differences persist between the Catholic and the Protestant ethic, greatly influencing family values. According to Greeley, the Catholic ethic is 'communitarian' while the Protestant is 'individualistic', because of different preconscious world views. 'Catholics are more likely to visit parents, children, siblings, and other relatives than are other Christians. [...] Net of national differences, then, Catholics do form more intense family networks than do other Christians [...]' (Greeley 1989, p. 497).

The results of the World Values Survey (WVS 1990-1993) confirm the fact that families in Italy and Spain are more often than in other countries the first vehicle to transmit religious beliefs. Virtually all Italians and Spaniards have been brought up with religious beliefs circulating in the home, in contrast to only the half in Central/Northern Europe (Eurobarometer 1993). The importance of the Church in the life of Italians and Spaniards is also supported by the high number of people who attend religious services at least once a week: $37.9 \%$ of Ital- 
ians, 29.2\% of Spaniards, and on average 11\% of Central/Northern Europeans. The importance of the Church and religion for family values is also reflected in the ideas people express when asked about family duties.

Ideas about duties between generations can be deduced from two questions of the WVS in 1990-93. First, a question about the duties towards parents. Over three-quarters of the Spaniards and Italians asked feel attached to their parents, independently of their behaviour and attitudes, whereas only about half of the Danes and West Germans asked do. Forty to $50 \%$ of the latter tend to support a more differentiated vision. This is similar to the values related to children.

Table 2: Love and Respect Parents and Parents Duties Related to Children, 1990-1993

\begin{tabular}{|c|c|c|c|c|c|c|c|}
\hline Column \%. How many people mentioned & Italy & Spain & DK & $\mathbf{F}$ & UK & BRD & Group-average \\
\hline $\begin{array}{l}\text { 'Regardless of what the qualities and faults of one's parents } \\
\text { are, one must always love and respect them' }\end{array}$ & 82.8 & 80.8 & 47 & 76.9 & 68.8 & 61.8 & 69.7 \\
\hline $\begin{array}{l}\text { 'One does not have the duty to respect and love parents who } \\
\text { have not earned it by their behaviour and attitudes' }\end{array}$ & 17.2 & 19.2 & 53 & 23.1 & 31.2 & 38.2 & 30.3 \\
\hline $\begin{array}{l}\text { 'Parents' duty is to do their best for their children even at the } \\
\text { expense of their own well-being' }\end{array}$ & 78 & 75.7 & 51.9 & 80.5 & 75.4 & 53.3 & 69.1 \\
\hline $\begin{array}{l}\text { 'Parents have a life of their own and should not be asked to } \\
\text { sacrifice their own well-being for the sake of their children' }\end{array}$ & 11.5 & 15.4 & 39 & 19.5 & 18.8 & 33.7 & 23 \\
\hline Neither & 10.5 & 8.9 & 9.1 & 0 & 5.8 & 12.9 & 7.8 \\
\hline
\end{tabular}

Source: World Values Survey, 1990-1993, var. 224.

With respect to the duties of parents in relation to children, three-quarters of the Spaniards and Italians asked express a family-oriented opinion, a somewhat lower percentage than the findings related to the parents. ${ }^{7}$ The group-average of the Central/Northern European is still different. These indicators from 1990-91 point to some cultural qualities that are found not only in Italy and Spain, but that help to explain great differences in behaviour.

The correlation between the indicators of religiosity and that of familiy duties suggests that the religious heritage seems to be important for family duties, independent of other socioeconomic factors. The core of religious heritage in Spain and Italy seems to be the high legitimacy of the Catholic doctrine about solidarity and reciprocal duties. But, the family is not valued in a similar way in all Catholic countries. The differences between countries with the same denomination also have to be related to the history of state-church relationships and the strength of the state. 


\section{THE SOUTHERN FAMILY MODEL}

In this paper we have proposed a theoretical model for analysing the family in Spain and Italy. Our findings on this model have been summarised in Figure 6.

\section{Figure 6: The Southern Family Model}

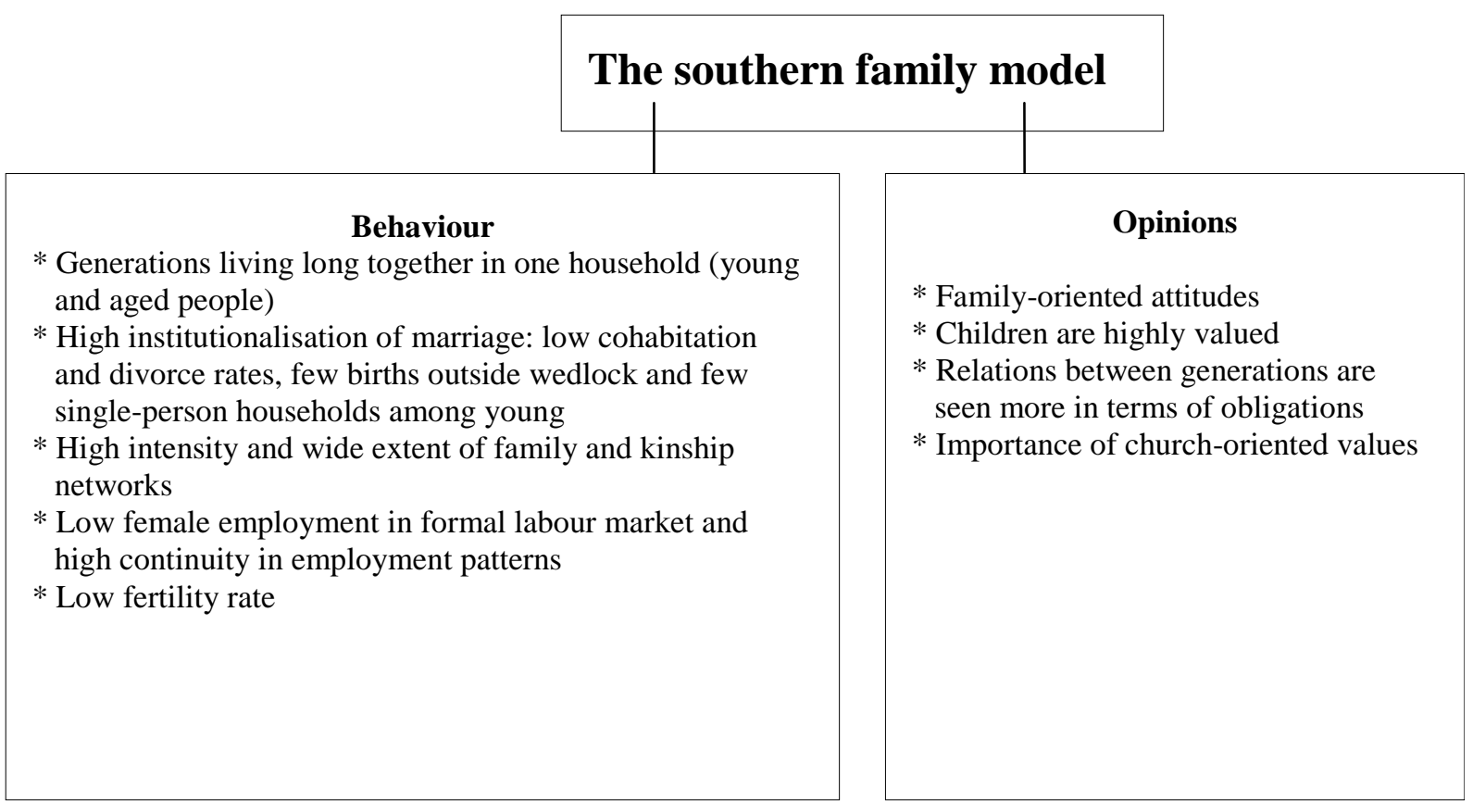

As the model shows, changes in this part of Europe point to incongruity and no clear shifts. Italian and Spanish families present indicators both of deep changes and of continuity. The most important changes are the increase in female employment which, together with a rapid modernization process, seems responsible for the increase in conjugal instability and for the rapid decline in fertility, which is, in its turn, related to the pattern of later marriages. However, we have found some indicators of permanence in 'traditional' patterns, too. Marriage as an institution is still very important and, as a consequence, birth outside marriage is still rare and divorce is not (yet) so widespread as in Centre/North Europe. To some extent cohabitation and living as a single young person (still very unusual phenomena) can be related to the strong institutionalization of marriage. On the other hand, the longer vertical extension of the family unit together with the relevance of church-oriented values can be associated with the high intensity of family and kinship ties as well as to the way in which the obligations between generations are perceived. The long dependence of young people on their parents is 
likely to be rooted in the high value attributed to children and in the low level of importance of 'independence' as an education value. The reverse of the coin is the propensity of people in the South to offer support to their parents during their old age.

Will this southern family model persist in the future or will it change? Are we only facing the problem of a cultural time lag? Here we want to unify our previous explanations and provide some ideas about the future development of the southern family model. Three factors seem to explain and favour the reproduction of the southern family model:

1. The socio-economic situation

2. The characteristics of social policies in Southern Europe

3. The family culture

1. It seems to us that the social structure in the South will continue to be different from that in Central/Northern European countries for as long as the economies of Italy and Spain continue to be characterised by: a) the subordinate role of these economies in the international division of work; b) the more intensive economic crisis, that is, higher and structural unemployment (characterised by a higher percentage of women, young people and long-term unemployed people); c) a labour market with many precarious jobs that affect young people and women in particular, high employment in agriculture, high rate of self-employed people as well as a higher rate of workers working in small enterprises (i.e. a high propensity to informal jobs); 4) few opportunities of part-time employment in the formal sector; and 5) the concentration of economic and social disadvantages in some areas and regions (cf. OECD 1994).

2. In Italy and Spain the entitlement and the level of public social benefits and social services are often related to the family unit and to family income. Social assistance, support for agricultural workers, family allowances, help for handicapped persons, scholarships, services for the aged, etc. are not institutionalized as individual social rights, but as social rights related to family income and family situation. Unemployment benefits for young persons seeking first employment are non-existent, as they are supposed to be supported by their family (Jurado Guerrero 1995). This is also often the case in Central/Nothern welfare states, but in Italy and Spain it seems to be more frequent. Similarly, family policies in both countries are not so highly developed, and are mainly targeted to families in need and are dependent on family income (Neubauer 1993). In particular, support for children is 'poor' in comparison with other European countries. The particular institutionalization of some social security laws con- 
cerning families must be seen partly as a result of the historical period in which social security was founded and partly as the result of specific socio-political contexts. The current crisis of welfare states will make it difficult to develop more generous family benefits as well as benefit related to individual rights.

3. The family and kin culture in the south is dominated by the relevance of children and family-oriented values, by the importance of obligations, by the solidarity between generations and by religious norms. Despite secularization processes, southern family culture maintains many traditional elements because it adapts well to a context of lasting employment shortage and a scarce availability of social services for families.

\section{Figure 7: Factors Pushing Towards the Reproduction of the Southern Family \\ Model}

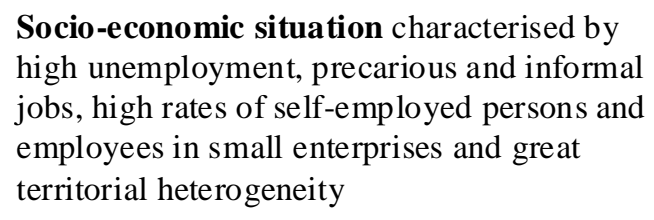

Continuity of a specific family and kin

culture and low level of secularisation.
Southern family model

characterised by long living together of the generations, high institutionalisation of marriage, strong kinship networks, low female employment, low fertility and strong family-oriented values.

From our point of view, the specific socio-economic development and current situation, the characteristics of social policies, and the scarce and regionally-differentiated diffusion of social services favour the persistence of the southern family model in Italy and Spain, as shown in Figure 7. The specific family and kin culture pushes in the same direction. These factors encourage solidarity between generations and within kin relationships and make the individualization of living arrangements more difficult. The family-oriented culture is surely a result 
of this economic and social situation as well as a legitimate factor for the present division of labour between the state and the family, between genders and generations in the labour market and within the family. In turn, the importance of the family and kinship networks is likely to favour social reproduction and inhibit social change, because of the greater probability of social control within the networks. All this forecasts the persistence of the southern family model.

Nevertheless, some factors could transform the existing model. The ongoing processes of secularization, the increasing educational level and the entrance of women into the labour market together with their wish to be economically independent will accelerate the renegotiation of relations between genders in favour of a more symmetrical relationship. The changing population structure, due mainly to fertility declines, will have an impact on the potential number of women available to care for the older generation and on the horizontal extension of the kinship networks as well. Therefore, it is equally likely to expect a deinstitutionalization of family solidarity and of marriage as the dominant family formation institution. 
Alberdi, C. and Alberdi, I. (1982): 'La institución matrimonial: Su lugar en la constelación familiar. Aspectos jurídicos y social del divorcio’, in R. Conde (ed.), Familia y cambio social en España, Madrid: CIS, pp. 24 - 41.

Alberdi, I., Flaquer, L. and Ussel, J. de (1994): Parejas y matrimonios: actitudes, comportamientos y experiencias, Madrid: Ministerio de Asuntos Sociales.

Alcaide Inchausti, J. (1988): 'El gasto publico en la democracia espanola. Los hechos', Papeles de economia espanola, 37, pp. 2-41.

Ascoli, U. (1984): Welfare State all'Italiana, Bari: Laterza.

Balbo, L. (1983): 'Il lavoro di servizio delle donne nella societa' capitalistica', in P. David and G. Vicarelli, G. (eds), L’azienda famiglia una societa' a responsabilita’ illimitata', Bari: Laterza, pp. 220-39.

Barbagli, M. (1990): Provando e riprovando. Matrimonio e divorzio in italia e negli altri paesi occidentali. Bologna: Il Mulino.

Borrajo Iniesta, S. (1990): La ruptura matrimonial en España, Madrid: Eudema.

Bradshaw, J. and Ditch, J. (1993): Support for children. A Comparison of Arrangements in Fifteen Countries, Research Report n, 21, London: HMSO.

Bruckner, E., Knaup, K. and Müller, W. (1993): Soziale Beziehungen und Hilfeleistungen in modernen Gesellschaften. Working Paper, Mannheim: Mannheim Centre for European Social Research.

Cavalli, A. et al.(1993): Terzo rapporto IARD sulla condizione giovanile in Italia, Bologna: Il Mulino

Commission of the European Community (1988): Young Europeans in 1987, Luxembourg: Commission of the European Community.

Conde, R. (1982): 'Desarrollo económico y cambio familiar: El impacto del nuevo rol femenino sobre la estructura de la familia', in R. Conde (ed.), Familia y cambio social en España, Madrid: CIS, pp.

Delgado Pérez, M. and Livi-Bacci, M. (1992): 'Fertility in Italy and Spain: The Lowest in the World', Family Planning Perspectives, 24 (4), pp. 162-171.

Delgado, M. (1993): 'Cambios recientes en el proceso de formación de la familia', Revista Española de Investigaciones Sociales, 64, pp. 123-153.

Eurobarometer (1991a): Young Europeans, 34.2., Brussels/Luxembourg: ECSC-EEC-EAEC.

Eurobarometer (1991b): Employment and Family Whitin the Twelve, 34, Brussels/Luxembourg: ECSC-EEC-EAEC.

Eurobarometer (1992): study number 37.2, data file obtained by Zentrum für Europäische Umfrageanalysen und Studien, Mannheim.

Eurobarometer (1993): Europeans and the Family, 39.0, Brussels/Luxembourg: ECSC-EEC-EAEC.

Eurostat (1992a): Employment and Unemployment, Luxembourg: Eurostat.

Eurostat (1991): Labour Force Survey, Results 1989, Bruxelles/Luxembourg: Eurostat.

Eurostat (1992b): Demographic Statistics 1992, Bruxelles, Luxemburg: Eurostat.

Eurostat (1993): Labour Force Survey, Results 1991, Luxembourg: Eurostat.

Ferrera, M. (1984): Welfare State in Italia. Sviluppo e crisi in prospettiva comparata, Bologna: Il Mulino.

Ferrera, M. (1994): Southern Welfare in Social Europe. Paper presented at the III Internaltional Seminar on Social Policy. Madrid, 24 October.

Flaquer, L. (1994): 'La nupcialidad', in M. Juárez (ed.), V. Informe sociológico sobre la situación social en España. Sociedad para todos en el año 2000, Madrid: FOESSA, pp.

Flora, P. (1985): 'On the History and Current Problems of the Welfare State', in S.N. Eisenstadtand O. Ahimeir (eds.), The Welfare State and its Aftermath,. London: Croom Helm, pp. 11 - 30.

Golini A. (1988): 'Profilo demografico della famiglia italiana', in P. Melograni (eds.), La famiglia italiana dall'ottocento ad oggi, Bari: Laterza, pp. 327-381.

Golini, A. and Menniti, A. (1994): 'Popolazione e famiglie', in Comitato per l'anno Internazionale della Famiglia, Per una Politica Familiare in Italia. Presidenza del Consiglio dei Ministri, Roma: Ministero per gli Affari Sociali, pp. 3-26. 
Goode, W (1993): World Changes in Divorce Patterns, Yale: Yale University Press.

Greeley, A. (1989): 'Protestant and Catholic: Is the Analogical Imagination extinct?', American Sociological Review, 54, august, pp. 485-502.

Guillén, A.M. (1992): 'Social Policy in Spain: From Dictatorship to Democracy’ (1939-1982), in Z. Ferge, and Kolberg, J.E. (eds), Social Policy in a Changing Europe, Frankfurt/M./Boulder: Campus and Westview Press, pp. 119-142.

Höllinger, F. and Haller, M. (1990): 'Kinship and Social Network in modern societies: a cross-cultural comparison among seven nations', European Sociological Review, 6(2), pp. 103-124.

INE (1991): Encuesta Sociodemográfica Resultados Nacionales, vol. 1, hogar y familia, Madrid: Instituto Nacional de Estadística.

ISSP (1986): Social Network and Support System, Koeln: Zentralarchiv fuer Empirische Sozialforschung. (The participating nations are: Austria, Australia, Great Britain, Hungary, Italy, United States d West Germany).

ISTAT (1993): Indagine Multiscopo sulle Famiglie anni 1987-91, Vol. 2, Roma: Istat.

Jepperson, R. L. (1991): 'Institutions, Institutional Effects and Institutionalism', in W. Powell and DiMaggio, P. J. (eds), The New Institutionalism in Organizational Analysis, Chicago/London: The University of Chicago Press, pp. 143-163.

Jurado Guerrero, T. (1995): 'Legitimation durch Sozialpolitik? Die spanische Beschäftigungskrise und die Theorie des Wohlfahrtsstaates', Kölner Zeitschrift für Soziologie und Sozialpsychologie, 47(4), pp. 727-752.

Lepsius, R. M. (1995): 'Institutionenanalyse und Institutionenpolitik’, Kölner Zeitschrift für Soziologie und Sozialpsychologie, Sonderheft 35, pp.

Menniti, A. et al.(1992): Changes in Family Life in the 1980’s. The Italian case. Relazione al II Working Group Meeting on Family Policy and Family Life, Bonn, aprile.

Muro, J., Raymond, J.L., Toharia, L. and Uriel, E. (1988): Análisis de las condiciones de vida y trabajo en España, Madrid: Ministerio de Economía y Hacienda. Secretaría de Estado de Economía.

MZES (1994): OECD Data Base, Mannheim: MZES, August.

Neubauer, E. et al. (1993): Zwölf Wege der Familienpolitik in der Europäischen Gemeinschaft. Eigenständige Systeme und vergleichbare Qualitäten? Studie im Auftrag des Bundeministeriums für Familie und Senioren, Stuttgart, Berlin, Köln: Kohlhammer.

OECD (1980)(1989)(1991): National Accounts of OECD countries. Paris: OECD.

OECD (1994): The OECD Jobs Study. Evidence and Explanations. Part I, Labour Market Trends and Underlying Forces of Change. Paris: OECD.

OECD (1995): National Accounts. Main Aggregates.Vol. 1. 1960-1993. Paris: OECD.

Paci, M. (1980): Famiglia e mercato del lavoro in una economia periferica, Milano: Angeli.

Paci, M. (1982): La struttura sociale Italiana, Bologna: Il Mulino.

Rapaport, R (1989): 'Ideologies about family forms: towards diversty', in K. Boh (ed.), Changing Patterns in European Family Life, London/NewYork: Routledge, pp. 53-70.

Roussel, L. (1992): 'La famille en Europe occidentale: divergences et convergences', Population, 1, pp. 133-152.

Roussel, L. (1994): 'La famille en europe occidentale depuis 1950', paper presented at the international conference, Bologna, Changes in Family patterns in western countries. 6-8 october, published by Comune di Bologna Assessorato alle politiche sociali e dell'immigrazione.

Sabbatini, L. L. (1994): 'Reti di relazioni familiari e tipologia della famiglia', in Comitato per l'anno Internazionale della Famiglia, Per una Politica Familiare in Italia. Presidenza del Consiglio dei Ministri, Roma: Ministero per gli Affari Sociali, pp. 173-89.

Saraceno C. (1994a) Family Policy and Family Changes in Italy, paper prepared for the conference on Family Changes and Family Policy, Mannheim, October.

Saraceno C. (1994b): Ambivalent Familism and Categorial Clientelism in the Italian Welfare State, paper presented at the III International Seminar on Social Policy, Madrid, October 24-28.

Solsona, M. (1991): 'The Problem of Measuring Women’s Work in Spain', Iberian Studies, 20(1\&2), pp. 6-28.

Valero, A. (1992): 'La prevalencia de la familia nuclear en el sistema familiar español', Revista Internacional de Sociologia. Tercera época, 3, septiembre-diciembre, pp. 183-210. 
Vincenzi Amato, D. (1988): 'Famiglie e il diritto', in P. Melograni (ed.), La famiglia italiana dall' Ottocento ad oggi, Bari: Laterza, pp. 629-99.

World Values Survey (1990-1993): Surveys coordinated and documented by Ronald Inglehart, Koeln: Zentralarchiv für empirische Sozialforschung, ICPSR Nr. 6160.

\footnotetext{
${ }^{1}$ We would like to thank Peter Flora for proposing the idea of writing this paper and for the useful comments he gave us during the writing process.

2 By the expression "family-oriented" countries we mean those realities characterised by strong families ties and familyoriented values.

${ }^{3}$ By degree of institutionalization we understand how far a social pattern is reproduced by routine, is associated with a system of sanctions, is taken for granted, and how far it structures behaviour (Jepperson 1991, Lepsius 1995).

${ }^{4}$ Because of the scarcity of regional statistics, national indicators are mainly used to make comparisons between countries. However, it should be mentioned that while these represent the "average" of sub-populations, within every country there are many variations at territorial and social levels. Their use is justified only by the same legislative, social and material constraints that citizens meet in their own country (Roussel 1992).

${ }^{5}$ The indicators chosen here can be analysed in a comparative way, because questions in this sense have been asked in the same way in international surveys. The interpretation of the results of comparative opinion surveys has to be made carefully, because the same question can produce different meanings across cultures and countries.

${ }^{6}$ In the ISSP (1986) people were asked who helps them in their homes and gardens, when they had influenza, suffered from depression, marital crisis, or needed financial help and advice about important changes in their lives.

${ }^{7}$ This could be attributed to the technical difference between the two questions: in the question here the possibility of answering "neither" was offered.
} 